\title{
The Absence of Freedom
}

\section{Debt, Bondage and Desire among Pakistani Brick Kiln Workers*}

\author{
Antonio De Lauri \\ Chr. Michelsen Institute, Norway \\ antonio.delauri@cmi.no
}

\begin{abstract}
Central and South Asian brick kilns have long attracted the attention of both humanitarian agencies and scholars as sites of slavery-like forms of labor exploitation. They represent both an important case study for investigating the systems of dependence and debt-relationships that characterize Southern Asian capitalism, and a big challenge to creating sustainable, international standards for human labor. One aspect largely overlooked in the literature concerns the ideas of freedom that emerge in situations of bondage. Based on ethnographic research conducted in brick kilns in the areas of Gujrat, Islamabad and Rawalpindi in 2015 and 2016, my analysis focuses on workers' narratives and their perceptions of freedom and its absence.
\end{abstract}

\section{Keywords}

debt bondage - Pakistan - brick kilns - freedom - dependence

Freedom, as the unlimited power of the negative, is presupposed, but not thematised.

ALAIN BADIOU, The Century

* Research was supported by the European Research Council under the European Union's Seventh Framework Programme (F P7/2007-2013), ERC Grant agreement 313737. 
Interference is sufficient for unfreedom.

Lack of means is unnecessary for unfreedom.

Interference is necessary for unfreedom.

Lack of means is insufficient for unfreedom.

GERALD ALLAN COHEN, On the Currency of Egalitarian Justice and other Essays in Political Philosophy

\section{Introduction}

In the past two decades the work of activists and scholars committed to the field of (anti-)slavery and human exploitation has converged on urgent communal goals such as giving voice to the enslaved and tackling the phenomena of exploitation and enslavement at an interdisciplinary and inter-sectorial level. Central and South Asian brick kilns have long attracted the attention of both humanitarian agencies and scholars as sites of slavery-like forms of labor exploitation. They represent both an important case study for investigating the systems of dependence and debt-relationships that characterize Southern Asian capitalism, and a big challenge to creating sustainable, international standards for human labor. The majority of international organizations, journalistic reports and scholarly debates on brick kilns have focused on issues such as child labor, workers' health, and the link between so-called modern slavery and the global political economy. Pakistan is considered to be one of the states where bondage and labor exploitation are most deeply entrenched, affecting the lives of millions of people. However, one aspect largely overlooked in the literature concerns the ideas of freedom that emerge in situations of bondage. Based on ethnographic research conducted in brick kilns in the areas of Gujarat, Islamabad and Rawalpindi in 2015 and 2016, my analysis focuses on workers' narratives and their perceptions of freedom and its absence.

\section{Pakistani Brick Kilns}

One of the most ancient in the region, ${ }^{1}$ the brick kiln industry throughout Central and South Asia is substantially governed by systems of extreme depen-

1 Anam Azam, "Victims of Circumstances: A Case Study to Explore the Socioeconomic Prob- 
dence and debt. ${ }^{2}$ Work organization within a kiln is structured according to different roles and duties, and workers have different kinds of contracts. The kilns that I visited employ from 150 to 300 workers, some of whom receive a regular salary. However, my study has mainly focused on those at the bottom of the kiln hierarchy who are mostly attracted by advances (peshgi, the sum loaned by the owner/creditor) and whose contracts are generally based on piecework. Peshgi varies on the basis of household productivity (e.g. a family may agree to produce 2,00o bricks per day) and negotiations between the owner of the kiln - who often leases the land from its owner with a contract that usually specifies the depth to which mud can be excavated — and the head of the household. All family members, including children, are then involved in brick production. Low-caste ${ }^{3}$ and migrant families - whose debt is generally larger than that of locals-live on the grounds of the kiln and can be involved in all the kiln's activities.

lems of Bounded Labor Working at Brick Kiln in Pakistan," International Journal of Business, Economics and Management Works 1 (2014): 1-5.

2 See, for example, Augendra Bhukuth, "Child Labour and Debt Bondage: A Case Study of Brick Kiln Workers in Southeast India," Journal of Asian and African Studies 40, no. 4 (2005): 287-302; Rabin Das, "Socio-Economic Conditions of Female Workers in Brick Kilns. An Exploitation to Healthy Social Structure: A Case Study on Khejuri CD Blocks in Purba Medinipur, West Bengal," International Journal of Science and Research 4, no. 1 (2013): 95-102; Aly Ercelawn and Muhammad Nauman, "Unfree Labour in South Asia: Debt Bondage at Brick Kilns in Pakistan," Economic and Political Weekly 39, no. 22 (2004): 2235-2242; Jayoti Gupta, "Informal Labour in Brick Kilns: Need for Regulation," Economic and Political Weekly 38, no. 31 (2003): 3282-3292; Muhammad Javaid Iqbal, "Bonded Labor in the Brick Kiln Industry of Pakistan," The Lahore Journal of Economics 11, no. 1 (2006): 99-119; Niaz Muhammad, Mussawar Shah, Intikhab Alam, Ali Askar, "Debt Bondage: A Sociological Study of Brick Kiln Workers in Badhaber, Peshawar, Pakistan," Pakistan Journal of Life and Social Sciences 8, no. 1 (2010): 19-23; D.P. Singh, "Women Workers in the Brick Kiln Industry in Haryana, India," Indian Journal of Gender Studies 12, no. 1 (2005): 83-97.

3 The role of caste in Pakistan has attracted little attention in public debates. As observed by Haris Gazdar, "There is little tolerance in the public domain of any serious discussion about caste and caste-based oppression, social hierarchies, and discrimination. The Right silences such talk by shouts of 'we are all Muslims' and 'caste is another country'-obvious which country that might be. In fact, the denunciation of 'the evil caste system' is a standard hymn in the rightist intellectual's repertoire on India, Hindus and the Two-Nation Theory. For the Left in Pakistan, when there was one, it was all about class. Caste or other societal sources of inequality and oppression were seen as unnecessary diversions from class struggle. The Left, of course, never succeeded in large-scale class mobilisation either, and it is tempting to put this failure down to sterilised and mechanical ideas about class that did not address societal 
All kilns incorporate a number of different working roles, each affording a different status in the labor hierarchy: pathera shapes the unbaked bricks, a job that includes the preparation of the clay, while the keri wala is in charge of spreading a mixture of clay and cinders on a set of stacked bricks prior to firing and baking; kharkar moves the bricks, usually on a donkey, from brick field to kiln or from kiln to stacks; bharai wala stacks unbaked bricks in the kiln and nikasi wala unloads them when baked; jalai wala's duty is firing the kiln and baking the bricks. Jamadar is a senior man among the patheras who arranges the labor, distributes advances, distributes earnings after debt-servicing deductions, guarantees repayment of debts and sometimes supervises the work. ${ }^{4}$ A full-time manager called munshi often acts as supervisor (and sometimes as subcontractor $)^{5}$ and also, on occasion, as a recruiter or mediator between creditor and debtor. Although it may not be immediately visible to an outsider, there are skill-based differentiations within the kiln: at the top of the hierarchy we find jalai walas, followed by bharai walas, patheras and nikasi walas. ${ }^{6}$

Mud bricks are prepared and sundried by patheras (the largest group of workers) from Saturday to Wednesday; work generally stops at midday on Thursday to start again later on Friday. A group of site-based, salaried jalai walas then bakes the bricks, working in six-hour shifts of two persons. This group is headed by a mistri, the skilled male leader of a labor group, who can recruit other team members. Firing the kiln and baking the bricks (jalai) is the most hazardous of kiln duties because it involves constant work with open fires: kiln openings need to be checked frequently in order to determine whether additional fuel is necessary to maintain the correct baking temperature and the extreme heat penetrates ordinary shoes. Six days a week baked bricks are removed from the kiln, categorized for quality and stacked up by a team of nikasi walas. Customers then take them away by bullock cart, tractor trolley or truck, mostly using their own laborers, though patheras or others from the kiln may take part for extra income. Several kilns bake without interruption throughout the year, though they may close for a short time if poor weather prevents the proper preparation of unbaked bricks or if the stock of unbaked

conditions." Haris Gazdar, "Class, Caste or Race: Veils over Social Oppression in Pakistan," Economic and Political Weekly 42, no. 2 (2007): 86-88.

4 PILER, “Unfree Labour in Pakistan: Work, Debt and Bondage in Brick Kilns," Pakistan Institute of Labour Education \& Research, Working Paper (2004): www.ilo.org.

5 Ali Khan, Laila Bushra and Hamid Sultan, "Brick Kilns Reviseted," in Ayaz Qureshi and Ali Khan, eds., Bonded Labour in Pakistan (Karachi: Oxford University Press, 2016).

6 Ali Khan, Laila Bushra and Hamid Sultan, "Brick Kilns Revisited." 
bricks is inadequate. Other kilns close for a fortnight or even more every three to four months, either to ensure a stable price, or because of pressure for higher piece rates by laborers or changing prices in other input supplies; a lack of working capital may also bring about periodic closure. ${ }^{7}$

Since a number of families live at the kiln sites, daily labor activities also include family work and caring for younger siblings. Children who live at the kiln do not go to school, which is something that characterizes child labor in the whole country: the vast majority of children who work do not go to school, although in other contexts children combine schooling with employment. ${ }^{8}$

In Pakistan, debt chains are essential drivers of the brick industry because they guarantee cheap (young) labor and a continuous supply of workers. Pakistani brick kilns, particularly in the Punjab and in the Khyber Pakhtunkhwa, are the chief primary-source industry in which bonded labor constitutes a consolidated reality. Most of the workers are attracted by the possibility of advances and, since repayment results in regular wage deductions, workers often need to ask for additional loans which cannot then be repaid, establishing a cycle whereby family loans can pass from one generation to the next. It is not uncommon for a debt to be sold off several times and to increase in interest rate in the process. Debts cannot usually be repaid completely, meaning that, instead of their debt following them, families are required to "follow" their debt from one kiln to another. During my fieldwork I met several families who have worked at a number of kilns over the past 30 years as their debt was continuously re-sold.

\section{Genealogies of Debt Bondage}

Tom Brass has acutely noted that if neoclassical economic theory precludes a connection between capitalism and unfreedom by reshaping the latter as free wage labor, postmodernism diminishes bondage as a fantasy of Western discourse, thereby erasing it from indigenous accumulation. ${ }^{9}$ Jan Breman has argued that bondage is an integral part of Indian capitalism. Although we could probably go further and affirm that bondage is intrinsic to capitalism in general,

$7 \quad$ PILER, "Unfree Labour in Pakistan: Work, Debt and Bondage in Brick Kilns."

8 Ranjan Ray, "Analysis of Child Labour in Peru and Pakistan: A Comparative Study," Journal of Population Economics 13, no. 1 (2000): 3-19.

9 Tom Brass, Towards a Comparative Political Economy of Unfree Labour. Case Studies and Debates (London: Frank Cass Publishers, 1999). 
the Dutch sociologist is certainly right when, reflecting on changes and similarities between historical forms of slavery, he emphasizes that we should not exaggerate "the protection and security enjoyed by landless labour in the precapitalist mode of production."10 And yet, in order to understand contemporary debt bondage in Pakistan, the advent of capitalism in India in the nineteenth century is highly relevant. Sudipto Mundle has provided a useful historical analysis in which he underlines the extent to which the infiltration of capital into land occurred through professional money-lenders' and merchants' acquiring a new interest in land, which took the form of wealthy families in the service of the aristocracy or the colonial government being attracted by land-profit. Even some of the landlords now had their privileges converted into a new and gainful addition to their private asset portfolio, which was priced on the market and exchangeable against money capital. According to Mundle this was the key moment of capital's penetration of agriculture: the capitalization of land. Of course, the capitalization of land and the formation of capital on the land were not the same thing. The main goal of the new owners of land-capital was to extract surplus from the land, which was not necessarily connected to investing in its development. It was the increasing physical exploitation of labor and not its expanded productivity that generated surplus product.11

Scholars of India are divided over when and how capitalism was established in colonial India. It seems to be undeniable, however, that objectification of social relations was already a reality in the late nineteenth century. This implies that both the global triumph of capitalism and also its Indian version lent power to the doctrine of progress and development as it was articulated in colonial discourse. It is in the context of this historical scenario that it is possible to understand how the history of debt bondage is intertwined with a movement towards free labor. ${ }^{12}$ As a consequence of capital's penetration of agriculture and the rising demand for labor to cultivate land, the social struc-

10 Jan Breman, "On Labour Bondage, Old and New," The Indian Journal of Labour Economics 51, no. 1 (2008): 83-90. Among Breman's major publications see, for instance, The Labouring Poor in India: Patterns of Exploitation, Subordination, and Exclusion (Delhi: Oxford University Press, 2003); The Making and Unmaking of an Industrial Working Class: Sliding Down the Labour Hierarchy in Ahmedabad, India (Amsterdam: Amsterdam University Press, 2004).

11 Sudipto Mundle, Backwardness and Bondage: Agrarian Relations in a South Bihar District (New Delhi: Indian Institute of Public Administration, 1979).

12 Gyan Prakash, Bonded Histories: Genealogies of Labor Servitude in Colonial India (Cambridge: Cambridge University Press, Cambridge, 1990). 
ture was challenged by massive internal mobility. Had the regular forces of supply and demand been allowed to develop in these circumstances it would unavoidably have led to a rise in wages. Labor became the crucial element of capitalism's high productivity technology and yet it was not high productivity but low wages and long working days that could guarantee a surplus product. ${ }^{13}$ The politics of wage control systematically characterized the origins of capitalism in India both in the agricultural and industrial sectors. ${ }^{14}$ In fact, while the supply and demand dynamic tended to push up the wage rate, capital could not profitably continue its penetration into the Indian economy unless it successfully imposed a low ceiling on earnings. It was usury through the instruments of indebtedness and debt bondage that governed the labor force. Both the vulnerable economic position of laborers and their dependence on loans were used as a hedge against the supply and demand conditions of labor itself, which would have otherwise been relatively favorable towards them. Loans were given to laborers in the credit market at a very high price, which was then extracted from them in the form of a low wage rate in the labor market, significantly below the rate which could have been produced by the trends of supply and demand in that market. ${ }^{15}$ In this context, one of the main objectives of internal migration in the country became the possibility of gaining access to cash in the form of loans. ${ }^{16}$ In order to consolidate this system, it was of fundamental importance that the laborers should be chronically in need of debt and so affected by the needs of survival that they would never be able to get out of the debt trap. In this crucial historical moment it is thus essential to distinguish the new relationship of debt bondage (kamiuti) from the traditional relationship of forced labor (begari). ${ }^{17}$

At the international level, debt bondage began to be recognized as a form of slavery with the 1956 Supplementary Convention on the Abolition of Slavery, the Slave Trade, and Institutions and Practices Similar to Slavery, a United Nations treaty that was intended to integrate the Slavery Convention signed in Geneva on 25 September $1926^{18}$ and the 1930 Convention Concerning Forced

13 Mundle, Backwardness and Bondage.

14 Rajnarayan Chandavarkar, The Origins of Industrial Capitalism in India. Business Strategies and the Working Classes in Bombay, 1900-1949 (Cambridge: Cambridge University Press, 1994).

15 Mundle, Backwardness and Bondage.

16 Chandavarkar, The Origins of Industrial Capitalism in India.

17 Mundle, Backwardness and Bondage.

18 See Jean Allain, The Slavery Conventions. The Travaux Préparatoires of the 1926 League of Nations Convention and the 1956 United Nations Convention (Leiden: Brill, 2008). 
or Compulsory Labour of the International Labour Organization (ILO). Pakistan signed the Supplementary Convention on 20 March 1958. Article 11(1) of the 1973 Pakistan constitution prohibited slavery and forced labor and, although the constitution explicitly denied the existence of bonded labor in Pakistan, ${ }^{19}$ in 1992 the Bonded Labour (Abolition) System Act (BLASA) was enacted and its rules were formulated in 1995. The Prevention and Control of Human Trafficking Ordinance was enacted in 2002. This legal arsenal notwithstanding, debt bondage is still reported in several sectors of the Pakistan economy. ${ }^{20}$

Together with changes, there are, then, strong historical continuities between different forms of bondage on the Indian subcontinent. As Breman maintains, neo-bondage can be considered the consequence of indebtedness and in both old and new bondage the unfree labor relationship is not the result of extra-economic force. Workers enter into the contract voluntarily to the extent that they have to repay the advances received, thus losing room for manoeuvre. ${ }^{21}$ Indeed, bonded labor is ex-ante voluntary: debtors voluntarily place themselves in a subordinate and servile position, even though they may have little choice in the matter. The bonded laborer is a technically free wage worker whose relationship with the creditor may be terminated on payment of the debt. Therefore, although once bonded a worker is unfree, the act that creates the bonded relationship is usually one freely made to avert extreme poverty. ${ }^{22}$ This idea of voluntary choice is usually critiqued on the basis that poor people have an extremely limited set of alternatives and are therefore forced in certain directions by external conditions. Yet this explanation may be incomplete as it rests on the assumption that the set of choices that an individual faces is (only) exogenously determined. But in reality the range of possibilities existing for a given person at a given time is (also) endogenous. ${ }^{23}$ It is in fact through a combination of micro and macro elements-

19 Ayaz Qureshi and Ali Khan, "Introduction" in Qureshi and Khan, eds., Bonded Labour in Pakistan.

20 Nicolas Martin, "The Political Economy of Bonded Labour in the Pakistani Punjab," Contributions to Indian Sociology 43, no. 1 (2009): 35-59; Krishna Upadhyayam, "Bonded Labour in South Asia: India, Nepal and Pakistan" in Christien Van den Anker, ed., The Political Economy of New Slavery (New York: Palgrave, 2004); Qureshi and Khan, eds., Bonded Labour in Pakistan.

21 Breman, "On Labour Bondage, Old and New."

22 Garance Genicot, "Bonded Labor and Serfdom: A Paradox of Voluntary Choice," Journal of Development Economics 67, no. 1 (2002): 101-127.

23 Genicot, "Bonded Labor and Serfdom." 
both voluntary choice and external forces - that debt is transformed into a principal vector of social relations and exploitation.

Today, public debt (domestic and external) affects Pakistan's economic growth in severe ways. ${ }^{24}$ Although analyses of debt generally fail to connect the different scales of debt (from public debt to debt bondage) or to consider the extent to which they are the expression of the same economic model and cultural universe, it is clear that debt develops through circular dynamics ${ }^{25}$ linking individual struggles with political economic plans. In Pakistan, the lack of access to credit, a surplus of human workforce, internal migration and lowcaste social immobility foster forms of exploitation based on debt. Comparatively the phenomenon is interregionally distributed and it is not surprising that debt bondage is today described as the most common form of servitude globally. ${ }^{26}$

\section{Narratives of Unfree Lives}

While conducting fieldwork among brick kiln workers I was struck by the fact that it was not bondage but more specifically the absence of freedom that characterized workers' narratives. Historically, the notion of freedom in Pakistan has mostly been discussed in religious and ethnic terms as applied in the realms of judicial practice ${ }^{27}$ and in government politics. Fieldwork raised new questions related to the need to understand whether and to what extent the relationship between dependence and debt should be more aptly addressed in terms of absence of freedom. We know that freedom is one of the most general notions used to qualify human action ${ }^{28}$ and its meanings and practices vary in

24 Muhammad Ramzan Sheikh, Muhammad Zahir Faridi and Khadija Tariq, "Domestic Debt and Economic Growth in Pakistan: An Empirical Analysis," Pakistan Journal of Social Sciences 30, no. 2 (2010): 373-387.

25 Syed Sajid Ali and Sadia Badar, "Dynamics of Circular Debt in Pakistan and Its Resolution," The Lahore Journal of Economics 15 (2010): 61-74.

26 David Graeber, Debt. The First 5,ooo Years (New York: Melville House, 2011); Sarah Knight, "Debt-Bondage Slavery in India," Global Dialogue 14, no. 2 (2012), www.worlddialogue.org. See also Genevieve LeBaron, "Reconceptualizing Debt Bondage: Debt as a Class-based Form of Labor Discipline," Critical Sociology 40, no. 5 (2014): 763-780.

27 See, for example, Tayyab Mahmud, "Freedom of Religion and Religious Minorities in Pakistan: A Study of Judicial Practice," Fordham International Law Journal 19 (1995): 40100.

28 David Kelly, "Freedom-A Eurasian Mosaic," in David Kelly and Anthony Reid, eds., 
time and space. Today we tend to take it for granted that a neoliberal formulation of freedom is based on concepts such as autonomy and independence, and a number of anthropologists, in the wake of Igor Kopytoff, ${ }^{29}$ have explained that this neoliberal definition does not apply to many societies in Africa and Asia where freedom, belonging and dependence are expressions of the same episteme. James Ferguson has, for example, argued that there are important historical reasons why the display of social groups seeking out their own subjugation and dependence makes us somewhat uncomfortable. According to Ferguson, the noble history of anti-slavery and anti-colonial battles makes it too easy for us to link ideas such as human dignity with autonomy and independence. For this reason a will to dependence seems shameful (and perhaps even painful). In this perspective, dependence is a form of bondage, the very opposite of freedom..$^{30}$

Ali Khan, ${ }^{31}$ in his study of the Pakistani football-stitching and banglemaking industries, somehow restores the practice of peshgi by contesting the direct relationship between advances and debt bondage. While such a relationship may be at stake in some contexts, Khan affirms, it is not automatic that pesghi is always followed by debt bondage. Khan argues that mediating elements, such as feelings of a shared common origin between employers and workers, play a positive role in worker-employer relationships. According to Khan, shared history is what makes the difference in Sialkot and Hyderabad, the places in which he has conducted ethnographic research. It is true thatas also happens in the brick industry-debt bondage radicalizes in situations in which low-caste families and migrants are involved, but this may be related to the greater vulnerability of these social groups rather than to the degree of proximity between locals and owners. Khan's view seems to foster an optimistic perception of social proximity that, however, underestimates the weight and forces of familial and interfamilial systems of dependence. A more intense level of solidarity among socially connected individuals produces a higher level of

Asian Freedom. The Idea of Freedom in East and Southeast Asia (Cambridge: Cambridge University Press, 1998).

29 See for instance Suzanne Miers and Igor Kopytoff, Slavery in Africa: Historical and Anthropological Perspectives (Madison: University of Wisconsin Press, 1979); Igor Kopytoff, "Slavery," Annual Review of Anthropology 11 (1982): 207-230.

$30 \quad$ James Ferguson, "Declarations of Declarations of Dependence: Labour, Personhood, and Welfare in Southern Africa," Journal of the Royal Anthropological Institute 19, no. 2 (2013): 223-242.

31 Ali Khan, "Peshgi Without Bondage: Reconsidering the Links between Debt and Bonded Labour," Cultural Dynamics 22, no. 3 (2010): 247-266. 
protection, but it is worth recalling the Latin etymology of solidarity used in commercial and civil law: obligatio in solidum, which includes the duty of fully paying a debt. In fact, a higher level of protection also implies a higher level of control and dependence. And, in situations of poverty and deprivation, dependence is very often a step toward exploitation. I would suggest that an idealistic apologia of dependence is not capable of specifying that, while dependence may be seen as a means of survival in conditions of poverty, it remains a crucial social mechanism for enabling human exploitation. Of course I am not referring here to a generic notion of dependence (every single human being intrinsically depends on others) but to the specific form of dependence that nourishes practices of belonging and ideas of identity in concrete circumstances.

In her review of David Bidney's edited book, The Concept of Freedom in Anthropology (1963), Margaret Mead argued that reflection on freedom is meaningful to anthropologists only if it is well grounded in culture area. For historians, such reflection needs to be grounded in period and place. Taken as a whole, Mead lamented, Bidney's book failed to "distinguish between freedom as an objective category used by the observer and an intra-ethnic category of a particular culture." 32 Articulated in manifold ways by philosophers over the centuries, freedom as a natural right also owes its existence to the consolidation of bourgeois social relations in modernity. By configuring labor power as an exchangeable commodity, capitalism created a formal juxtaposition between slavery and free labor. ${ }^{33}$ Debt bondage is emblematic in recomposing such a juxtaposition by showing the extent to which free choices can lead to unfree lives.

My use of the notion of freedom (azaadi in Urdu, from the Persian, azadi) in the Pakistani brick kiln context builds on the emphasis workers place on its absence. Waheed, a Punjabi man who has been working in kilns for more than twenty years, told me:

When you have a job you don't have to complain too much. This is what I have learnt in my life. [...] I'm not free to run away, to do something else. I'm here today and I will be here tomorrow too. The same for my children. [...] Whatever I do, it will never free me from this. Perhaps I will move to another kiln, but my condition will be the same. ${ }^{34}$

\footnotetext{
32 Margaret Mead, "Review," American Anthropologist 66, no. 6 (1964): 1402-1403.

33 Prakash, Bonded Histories.

34 Conversation with Waheed, 23 Jun. 2015, Gujrat, Pakistan.
} 
The feeling of absence of freedom was also implied in the story recounted by Ali, a 22-year-old man who started kiln work at the age of 19 after having asked for a loan in order to get married.

I met my wife the day we got married. She is a good wife. We want children, even though this is not a good life for children. I am illiterate. My wife is illiterate. I have my job but I don't earn enough money because I have to pay back the peshgi I requested three years ago. I would like to pay this money back but I can't. Mr. Sami [the owner of the kiln] is free to tell me "Ok Ali, you can go" [Ali laughs], but he will not do it. He is free. I'm not. ${ }^{35}$

When in October 2015 I met another man, Faisal, in a kiln nearby Rawalpindi, he was 41 and he told me he had been living at different brick kilns for 25 years. His son and his two daughters grew up at brick kilns. Faisal told me that "pesghi is the only possibility we have to fulfil our duties in society. [...] There are several issues to think about, for example dowry." ${ }^{36}$ While in urban areas dowry (or jahez) has essentially transformed into a groomprice, in rural areas it works as a pre-mortem inheritance mechanism. ${ }^{37}$ During our interview Faisal emphasized the social constraints he has to respect as head of his household, including past remittances to his natal family and now the marriages of his children. Debt, in Faisal's view, is the consequence of these social constraints and forms of dependence. "There are things you have to do in your life, no matter whether you like it or not. If I could run my own business I could do all the good things I have in mind. But I'm here. I'm just here."38

Scholars have long discussed the relationship between different forms of bondage and slavery. ${ }^{39}$ It has been argued that the creditor's claims over the debtor's labor-power are so pervasive that debt evidently prevents debtors from

35 Conversation with Ali, 2 Nov. 2015, Rawalpindi, Pakistan.

36 Interview with Faisal, 3 Nov. 2015, Rawalpindi, Pakistan.

37 Siwan Anderson, "The Economics of Dowry Payments in Pakistan" (2000) CentER Working Paper no. 82. See also J. Henry Korson, "The Roles of Dower and Dowry as Indicators of Social Change in Pakistan," Journal of Marriage and Family 30, no. 4 (1968): 696-707.

38 Interview with Faisal, 3 Nov. 2016, Rawalpindi, Pakistan.

39 Kevin Bales, Disposable People:New Slavery in the Global Economy (Berkeley and Los Angeles: California University Press, 2012); Gwyn Campbell and Alessandro Stanziani, eds., Bonded Labour and Debt in the Indian Ocean World (London: Pickering \& Chatto, 2013); Benedicte Hjejle, "Slavery and Agricultural Bondage in South India in the Nineteenth Century," Scandinavian Economic History Review 15 (1967): 71-126; Martin A. Klein, ed., Breaking the Chains: Slavery, Bondage, and Emancipation in Modern Africa and Asia (Madison: The University of Wisconsin Press, 1993); Genevieve Lebaron and Alison Ayers, "The 
enjoying self-mastery through their ownership of their labor as a form of property, a situation visibly at odds with liberal understandings of freedom. And yet, Julia O'Connell Davidson argues, the ubiquity of indebtedness amongst the poor means that even these aspects are not enough, on their own, to delimit the boundaries of debt bondage in such a way as to fit with Kevin Bales' definition of modern slavery. ${ }^{40}$ Discussing the peshgi system, Kevin Bales ${ }^{41}$ writes that it is a terrible way to make a living, equally so for both children and adults, but no worse than several other kinds of work in the poor areas-and it is better than having no work at all. According to Bales, peshgi becomes a system of enslavement through debt bondage when the debt and the piece rate are significantly and dishonestly manipulated in such a way as to keep the worker permanently in debt, and violence is used to enforce the bondage. ${ }^{42}$

It is not my intention here to continue the discussion of whether or not brick kiln workers' debt should be considered a form of slavery. I rather wish to underline the link between the desire for freedom and the protracted condition of survival through which workers design their life trajectories. Desire here can be understood as the location of workers' struggle, ${ }^{43}$ the territory of social consciousness in which the perception of the absence of freedom materializes. Faisal once said:

I didn't realise I was not a free person until I asked for a second loan from the owner of the kiln. I was young at that time and needed money because my father didn't have a job. [...] There is no other way for people like us to get money. I wish I could do otherwise. [...] I have serious problems with my legs now, but when I was young I was fast. Yet I couldn't run anyway. ${ }^{44}$

Rise of a 'New Slavery'? Understanding African Unfree Labour through Neoliberalism," Third World Quarterly 34, no. 5 (2013): 873-892; Julia O'Connell Davidson, "New Slavery, Old Binaries: Human Trafficking and the Borders of 'Freedom,'” Global Networks 10, n. 2 (2010): 244-261; Joel Quirk, "Ending Slavery in All its Forms: Legal Abolition and Effective Emancipation in Historical Perspective," The International Journal of Human Rights 12, no. 4 (2008): 529-554.

40 Julia O'Connell Davidson, Modern Slavery: The Margins of Freedom (New York: Palgrave, 2015).

41 Bales, Disposable People.

42 O'Connell Davidson, Modern Slavery.

43 Gayatri C. Spivak, "Can the Subaltern Speak?” in Cary Nelson and Lawrence Grossberg, eds., Marxism and the Interpretation of Culture (Champaign: University of Illinois Press, 1988).

44 Interview with Faisal, 3 Nov. 2015, Rawalpindi, Pakistan. 
It is generally accepted in postcolonial and subaltern studies that economic and political deprivation are necessary conditions for resistance. ${ }^{45}$ Writing on India, Jan Breman ${ }^{46}$ has argued that bonded workers' efforts to live as decent human beings are the result of a long process of social emancipation. However, ethnography conducted in Punjabi brick kilns revealed only a marginal presence of ideologies of resistance and emancipation. Instead, the desire for freedom seems to co-exist with a diffused phenomenon of atomization, that is, a fragmented social context of individual struggles unconnected by sentiments of social class belonging. Although labor and the cycles of debt are embodied in complex social networks made of continuous exchanges and interactions at familial and inter-familial level, this social density falls apart as soon as workers reflect on their future and their working conditions. In their study of the Chennai brick kilns in India, a group of researchers ${ }^{47}$ also report that they have not encountered a single case of a union or any other form of collective action with the aim of claiming the rights of workers. In the Gujrat district of Pakistan there are a few workers' unions but so far they have had no impact on the brick sector, apart from a few individual legal cases, and there are also a handful of activists known in national and international media for their struggles for the rights of brick kiln workers. For example, Syeda Ghulam Fatima, a labor and human rights activist and General Secretary of the Bonded Labour Liberation Front (Lahore, Pakistan), has campaigned against bonded labor in the brick kiln industry in the following terms:

Throughout rural Pakistan, illiterate and desperate laborers are tricked into accepting small loans in exchange for agreeing to work at brick kilns for a small period of time. But due to predatory terms, their debt balloons, growing larger as time goes on, with no possibility of repayment, until these laborers are condemned to work for the rest of their lives for no compensation. If the laborer dies, the debt is passed on to his or her children. ${ }^{48}$

45 Sarmistha Pattanaik, "Tradition, Development and Environmental Movement of the Marginalised: A Study of Fishing Community's Resistance in Orissa," Indian Anthropologist 33, no. 1 (2003): 55-70.

46 Breman, "On Labour Bondage, Old and New."

47 Isabelle Guérin et al., "Labour in Brick Kilns: A Case Study in Chennai," Economic and Political Weekly 42, no. 7 (2007): 599-606.

48 http://www.humansofnewyork.com/post/126765531151/i-want-to-conclude-the-pakistan -series-by. 
However, these forms of action are the result of external intervention and very rarely translate into action from below. Like everywhere else, in the brick kiln context poverty and marginality must be seen in relation to the structural co-presence of other conditions of social life such as the inefficiency of infrastructures, the collapse of welfare and the way in which livelihoods are wilfully annihilated in the name of development or for the sake of the free market. At the convergence of these realms we can discern the variety of ways in which poverty is experienced and the forms of political action that are realized. ${ }^{49}$ Veena Das and Michael Walton have recently reminded us that, according to some political philosophers, given that the poor live on the brink of survival and are overwhelmed by their lack of basic needs, they are incapable of the kind of collective action that constitutes the realm of politics. However, what we need to understand is precisely what the poor do and in what ways they participate in political activities as part of their everyday lives. ${ }^{50}$ Yet to define what constitutes "action" in abstract terms is a difficult exercise. A diffuse sense of atomization dominates the brick kiln sector in Pakistan, resulting in a lack of effective organized collective action. But in order to understand "what the poor do" in this context we have to consider the way workers explicitly (and critically) address the atomization of their social affliction. Waheed, a Punjabi man who has been a kiln worker for 21 years, confirmed this to me during one of our conversations in Gujrat:

Everybody looks after his own interests. No matter that we are all in the same condition. If I need something I have to do it by myself. [...] Of course I care about my family, but that's it. [...]. There are 12 households living at this kiln, but none of us knows where we will be tomorrow. If someone needs money he will try to look for another owner who can pay the loan here and give him new advances. ${ }^{51}$

To some extent, both the desire for freedom and the atomization process consolidate the position of those who insist on underlining the individualistic ideology that lies behind neoliberal conceptions of freedom-today globally spread. Yet it is not possible to ignore the way in which workers/debtors wish to frame the existential condition in which they find themselves. While

49 Veena Das and Shalini Randeria, "Politics of the Urban Poor: Aesthetics, Ethics, Volatility, Precarity. An Introduction to Supplement 11," Current Anthropology 56 (2015): s3-S14.

50 Veena Das and Michael Walton, "Political Leadership and the Urban Poor Local Histories," Current Anthropology 56 (2015): S44-S54.

$5^{1}$ Conversation with Waheed, 23 Jun. 2015, Gujrat, Pakistan. 
activists, NGOs ${ }^{52}$ and international organizations, and modern slavery scholars reiterate an often metaphorical use of the notion of (new, modern, neo) slavery to describe the condition of brick kiln workers, the explicit desire for freedom that workers manifest is perhaps more revealing of the different constraints that demarcate their unfree life. It is more useful to identify debt bondage as the other side of the coin of free labor, one that is not a condition of brick kiln workers in isolation but, rather, conditional on their being part of the global capitalist mode of production. Debt radicalizes in a realm of free market and free labor. Therefore, debt bondage cannot be considered the consequence of traditional forced labor but, rather, the result of the unbalanced relationship between surplus, low wages and access to credit. Debt bondage in brick kilns is explicative of the contemporary trends in the global neoliberal economy in which the capitalist development and unfreedom link ${ }^{53}$ determines structural conditions of labor precariousness and social uncertainty.

\section{Conclusion}

Supplying credit to workers is central to the smooth flows of capital. The growth of credit markets and the expansion of related financial products reflect the increasing (global) proliferation of capital as a commodity. Debt circulates as a commodity without having being converted into productive use value, while surplus is generated not only through labor but also through circulation and speculation. ${ }^{54}$ On the one hand, the expansion of credit is seen in neoliberal theory as something that facilitates the voluntary choices of workers and families to maximize their assets and diversify their livelihoods to maximize

$5^{2}$ The role of NGOs deserves further reflection. In a critical vein, James Petras and Henry Veltmeyer argued that "NGo funding has led to a proliferation of competing groups, which set communities and groups against each other, undermining existing social movements. Rather than compensating for the social damage inflicted by free market policies and conditions of debt bondage, the NGO-channeled foreign aid complements the international financial institutions' neo-liberal agenda." James Petras and Henry Veltmeyer, "Age of Reverse Aid: Neo-liberalism as Catalyst of Regression," Development and Change 33, no. 2 (2002): 281-293.

53 Tom Brass, "Debating Capitalist Dynamics and Unfree Labour: A Missing Link?” The Journal of Development Studies 50, no. 4 (2014): 570-582.

54 Sohini Kar, "Recovering Debts: Microfinance Loan Officers and the Work of 'Proxy-Creditors' in India," American Ethnologist 40, no. 3 (2013): 480-493. 
income; on the other, the expansion of credit can exacerbate the risks faced by marginalized groups and poor families, leading to the profitable proliferation of debt traps..$^{55}$

In fact, debt, in itself, does not lead to bondage. Rather, the potential for that kind of exploitation emerges from the way in which indebtedness interacts with social, legal and economic uncertainty, and with social and cultural inequalities and injustices. In situations of vulnerability and social marginalization, debt can become the crucial link between a person's free choice and their unfree life. This is what emerges from the narrative of workers voluntarily taking on debts that they must repay. The monetary-capitalist morality that dominates the brick sector reflects the way in which modern-day bondage is deeply rooted in local social webs of inequality, with global connections and implications. A so-called free person may well create her debt by using the system of loans and advances, but in doing so she plays out at a micro level an entire macro context of inequality and dependence. The desire for freedom has a role in this picture as both the neoliberal expression of individual emancipation ideology and the location of workers' struggle, the link between survival and the future.

55 Marcus Taylor, “'Freedom from Poverty is Not for Free.' Rural Development and the Microfinance Crisis in Andhra Pradesh, India," Journal of Agrarian Change 11, no. 4 (2011): 484-504. 